\title{
Pathological features of glomerulonephritis in Jakarta
}

\author{
Sutisna Himawan
}

\begin{abstract}
Abstrak
Semua kasus biopsi ginjal yang diterima selama 10 tahun dari 1990-1999 dikumpulkan dan diteliti. Seluruhnya terdapat 1344 kasus, terdiri atas 390 kasus pediatrik, 918 kasus dewasa dan 36 kasus yang usianya tidak diketahui. Tujuan penelitian ini ialah untuk mendapatkan gambaran tentang pola dan spektrum penyakit glomerulus di Indonesia, terutama di Jakarta dan sekitarnya, dengan perhatian khusus pada kasus sindrom nefrotik, nefritis lupus dan nefropati IgA, serta membandingkannya dengan berbagai laporan terdahulu dari Indonesia dan beberapa negara lain. Terdapat 250 kasus sindrom nefrotik pada anak dan 479 kasus dewasa. Diagnosis histopatologik yang paling sering pada kedua golongan ialah penyakit kelainan minimal, yaitu masing-masing sebanyak $58.2 \%$ dan $44.7 \%$. Pria lebih sering terkena daripada wanita dengan perbandingan untuk masing-masing golongan ialah 2.0 .1 dan 1.4:1. Nefritis lupus meliputi 124 kasus, tiga diantaranya tidak representatif. Perbandingan pria terhadap wanita ialah 1:7.9. Frekuensi puncak terdapat pada dekade keempat sebanyak 47 kasus (38.5\%) dan gambaran histopatologik terbanyak ialah WHO kelas IV, yaitu 71 kasus (58.7\%). Diagnosis nefropati IgA ditegakkan pada 97 kasus. Sebaran usia dari 3 hingga 58 tahun dengan puncak insidens pada dekade keempat dengan 32 kasus (33\%). Pria lebih sering dari wanita dengan perbandingan 1.7:1. Gambaran histopatologik terbanyak ialah lesi sklerosis difus 34 kasus (35\%) dan lesi proliferatif mesangial 33 kasus (34\%). (Med J Indones 2002; 11: 24-9)
\end{abstract}

\begin{abstract}
All cases of renal biopsies received during a 10-year period from 1990-1999 were collected and analyzed. There were a total of 1344 cases, comprising 390 pediatric cases, 918 adult cases and 36 cases of unknown age. Immunofluorescence microscopy was performed on 1089 cases $(81.0 \%)$. The purpose of this study is to have an overview of the pattern and spectrum of glomerular diseases in Indonesia, especially in Jakarta and surroundings, with special emphasis on the cases with nephrotic syndrome, lupus nephritis and IgA nephropathy, and to compare the findings with previous reports from Indonesia and a few other countries. There were 250 cases of childhood nephrotic syndrome and 479 adult cases. The most frequent histopathological appearance in both groups was minimal change disease, i.e. $58.2 \%$ and $44.7 \%$ respectively. Males were more often affected than females with a ratio of $2.0: 1$ for children and 1.4:1 for adults. Lupus nephritis comprised 124 cases, among which three cases were not representative. The male to female ratio was 1:7.9. Most cases were in the fourth decade, i.e. 47 cases $(38.5 \%)$, and the most frequent histopathological appearance was WHO class $I V$ with 71 cases (58.7\%). There were 97 cases of IgA nephropathy with an age range between 3 to 58 years. The peak incidence was in the fourth decade with 32 cases (33\%). The male to female ratio was 1.7:1. The most frequent histopathological appearances were diffuse sclerosing lesion 34 cases (35\%) and mesangial proliferative lesion 33 cases (34\%). (Med J Indones 2002; 11: 24-9)
\end{abstract}

Keywords: renal biopsy, pathological features, glomerulonephritis, nephrotic syndrome, lupus nephritis, IgA nephropathy

The first report of percutaneous renal biopsy in Jakarta was published by Sutedjo and Wahidijat ${ }^{1}$ in 1963. They described the histopathological findings in three cases of children with nephrotic syndrome. However, due to lack of facilities and various other reasons the renal biopsies were discontinued and only in 1970 it was started again. ${ }^{2}$ Since then it became a routine procedure in the Sub-departments of Nephrology

Department of Anatomic Pathology, Faculty of Medicine University of Indonèsia/Dr. Cipto Mangunkusumo Hospital, Jakarta, Indonesia

Presented at the $13^{\text {th }}$ Asian Colloquium in Nephrology, Bali, November 23-25, 2000 of the Department of Child Health and the Department of Internal Medicine of the Faculty of Medicine University of Indonesia/Dr. Cipto Mangunkusumo National Central General Hospital. At that time the only private hospital which also performed this procedure was the Cikini Hospital, who had developed a very solid nephrology team. Nowadays it is also performed sporadically in a few other private hospitals. Besides percutaneous renal biopsy, in a part of the cases an open renal biopsy was performed to avoid the possibility of an unrepresentative specimen.

During the early 1970 s the pathological diagnosis of renal biopsies was only based on light microscopy 
findings. In 1976 facilities for immunofluorescence microscopy was established. Unfortunately until now there is still no facility for electron microscopy.

The purpose of this study is to have an overview of the spectrum and pattern of the various renal diseases in Indonesia, especially in Jakarta and surroundings, during the last decade of the twentieth century, and also to compare it with previous findings from Indonesia, as well as a few reports from other countries.

\section{METHODS}

All cases of renal biopsies received at the Department of Anatomic Pathology of the Faculty of Medicine University of Indonesia/Dr. Cipto Mangunkusumo National Central General Hospital during a 10-year period from 1990 until 1999 were collected from the files and analyzed according to the clinical diagnosis, age, gender and pathological diagnosis.

The nomenclature and classification used were in accordance with the WHO criteria., ${ }^{3,4}$ For the light microscopy examination the paraffin blocks were cut in two micron sections and stained routinely with hematoxylin and eosin (H\&E), periodic acid-Schiff. (PAS) and Masson-Goldner's trichrome (MT). Staining with periodic acid-silver methenamine (PASM) was also applied in cases which showed thickening of the capillary walls. While for immunofluorescence microscopy the specimen was tested against IgG, IgA, IgM, $\mathrm{C} 3$ and fibrinogen. In this study evaluation will be limited to cases with the nephrotic syndrome, lupus nephritis and $\operatorname{Ig}$ A nephropathy.

\section{RESULTS}

The total number of renal biopsies received during a 10-year period from 1990-1999 was 1344 cases, comprising 390 pediatric cases, 918 adult cases and 36 cases of unknown age, among which 214 cases were not representative, thus only 1130 could be evaluated. Cases were regarded not representative if the microscopical slide showed less than six glomeruli, with the exception of certain cases like membranous nephropathy and amyloidosis in which a definite diagnosis could be established even with less than six glomeruli.

Immunofluorescence microscopy was performed on 1089 cases (i.e. $81.0 \%$ of all cases), among which 242 cases were not representative, thus only 847 cases could be evaluated.

\section{Nephrotic syndrome}

More than half of the renal biopsies, i.e. 729 cases (54.2\%) were sent for the pathological evaluation of patients with the nephrotic syndrome, comprising 250 pediatric cases, among which 177 (70.8\%) were representative, and 479 adult cases, among which 387 $(80.8 \%)$ were representative, thus the total number of cases which could be evaluated was 564. The distribution of the pathological diagnoses is shown in Table 1.

Table 1. Distribution of pathological diagnoses among the cases with nephrotic syndrome

\begin{tabular}{lccr}
\hline & Childhood & Adult & Total \\
\hline Minimal change & 103 & 173 & 276 \\
Mesangial PGN & 22 & 59 & 81 \\
FSGS & 14 & 48 & 62 \\
MPGN & 23 & 34 & 57 \\
Membranous GN & 3 & 26 & 29 \\
Lupus nephritis & 4 & 18 & 22 \\
IgA nephropathy & 2 & 6 & 8 \\
Amyloidosis & 1 & 7 & 8 \\
Diabetic nephropathy & 0 & 4 & 4 \\
Crescentic GN & 1 & 2 & 3 \\
Diff. sclerosing GN & 4 & 10 & 14 \\
Not representative & 73 & 92 & 165 \\
\hline Total & 250 & 479 & 729 \\
\hline
\end{tabular}

The most frequent pathological diagnoses were minimal change, i.e. 276 cases $(48.9 \%$ ), with respectively 103 pediatric cases and 173 adult cases, followed by mesangial proliferative glomerulonephritis 81 cases (14.4\%), focal segmental glomerulosclerosis 62 cases $(11 \%)$, membranoproliferative glomerulonephritis 57 cases $(10.1 \%)$ and membranous glomerulonephritis only 29 cases $(5.1 \%)$.

The five most frequent pathological diagnoses in childhood nephrotic syndrome are shown in Table 2.

Table 2. The five most frequent pathological diagnoses in cases of childhood nephrotic syndrome

\begin{tabular}{lcc}
\hline & Number & $\%$ \\
\hline Minimal change & 103 & 58.2 \\
MPGN & 23 & 13 \\
Mesangial PGN & 22 & 12.4 \\
FSGS & 14 & 7.9 \\
IgA nephropathy & 5 & 2.8 \\
\hline
\end{tabular}


The most frequent pathological diagnoses were as follows: minimal change 103 cases $(58.2 \%)$, membranoproliferative glomerulonephritis 23 cases (13\%), mesangial proliferative glomerulonephritis 22 cases (12.4\%), focal segmental glomerulosclerosis 14 cases (7.9\%) and IgA nephropathy 5 cases (2.8\%). Minimal change disease comprised $58.2 \%$ of all cases and the nonminimal change $41.8 \%$; with a ratio of $1.4: 1$. The male to female ratio was $2: 1$.

The five most frequent pathological diagnoses in adult nephrotic syndrome are shown in Table 3.

Table 3. The five most frequent pathological diagnoses in adult nephrotic syndrome

\begin{tabular}{lcc}
\hline & Number & $\%$ \\
\hline Minimal change & 173 & 44.7 \\
Mesangial PGN & 55 & 14.2 \\
FSGS & 45 & 11.6 \\
MPGN & 31 & 8.0 \\
Membranous GN & 25 & 6.5 \\
\hline
\end{tabular}

The most frequent pathological diagnosis in adults was also minimal change, i.e. 173 cases $(44.7 \%)$, followed by mesangial proliferative glomerulonephritis 55 cases $(14.2 \%)$, focal segmental glomerulosclerosis 45 cases $(11.6 \%)$, membranoproliferative glomerulonephritis 31 cases $(8.0 \%)$ and membranous glomerulonephritis 25 cases $(6.5 \%)$.

The ratio of cases with minimal to nonminimal change disease was $1: 1.2(173: 214)$.

The male to female ratio was $1.4: 1$.

\section{Lupus nephritis}

Lupus nephritis comprised 124 cases, with a male to female ratio of 1:7.9 (14:110).

The age distribution can be seen in Table 4 .

Table 4. Age-group distribution of lupus nephritis cases

\begin{tabular}{lccc}
\hline Age (year) & Male & Female & Number \\
\hline $0-9$ & 1 & 2 & 3 \\
$10-19$ & 6 & 14 & 20 \\
$20-29$ & 3 & 17 & 20 \\
$30-39$ & 2 & 43 & 45 \\
$40-49$ & 1 & 34 & 35 \\
$>50$ & 0 & 0 & 0 \\
Unknown & 1 & 0 & 1 \\
\hline Total & 14 & 110 & 124 \\
\hline
\end{tabular}

Most cases were in the fourth decade, i.e. 45 cases (38.5\%), followed by the fifth decade 35 cases $(29.6 \%)$ and the second and third decade each 26 cases $(21.3 \%)$.

The distribution of the pathological diagnoses using the WHO classification ${ }^{4}$ is shown in Table 5.

Table 5. Distribution of pathological diagnoses in lupus nephritis according WHO classification

\begin{tabular}{lcr}
\hline Class & Number & $\%$ \\
\hline I & 12 & 9.9 \\
II & 11 & 9.1 \\
III & 12 & 9.9 \\
IV & 71 & 58.7 \\
V & 11 & 9.1 \\
VI & 4 & 3.3 \\
\hline Total & 121 & 100 \\
\hline
\end{tabular}

* 3 cases were not representative

The highest number of cases were classified as Class IV, i.e. 71 cases $(58.7 \%)$, followed by Class I and Class III 12 cases (9.9\%) each, Class II and Class V also with a same number, i.e. 11 cases $(9.1 \%)$, and Class VI 4 cases $(3.3 \%)$.

\section{IgA Nephropathy}

There were 97 cases of $\operatorname{IgA}$ nephropathy with various histopathological appearances as is shown in Table 6.

Table 6. Distribution of histopathological appearance of IgA nephropathy cases

\begin{tabular}{lcc}
\hline & Number & $\%$ \\
\hline Diff. sclerosing GN & 34 & 35 \\
Mesangial PGN & 33 & 34 \\
Focal sclerosing & 19 & 19.6 \\
Minor change & 6 & 6.2 \\
Chronic rejection & 1 & 1 \\
Unclassified & 4 & 4.1 \\
\hline Total & 97 & 100 \\
\hline
\end{tabular}

The most frequent picture was diffuse sclerosing lesion which was found in 34 cases (35\%), followed by mesangial proliferative lesion 33 cases (34\%), focal sclerosing lesion 19 cases (19.6\%), minor lesion 6 cases $(6.2 \%)$, unclassified 4 cases $(4.1 \%)$ and one case $(1 \%)$ was found in a chronic transplant rejection. The male to female ratio was $1.7: 1$ (61:36), and the age range was between 3 to 58 years.

The age group distribution is shown in Table 7. 
Table 7. Age group distribution of IgA nephropathy cases

\begin{tabular}{lcc}
\hline Age (year) & Number & $\%$ \\
\hline $0-9$ & 6 & 6.2 \\
$10-19$ & 13 & 13.4 \\
$20-29$ & 20 & 20.6 \\
$30-39$ & 32 & 33 \\
$0-49$ & 20 & 20.6 \\
$>50$ & 4 & 4.1 \\
Unknown & 2 & 2.1 \\
\hline Total & 97 & 100 \\
\hline
\end{tabular}

The highest frequency was found in the fourth decade with 32 cases $(33 \%)$, followed by the third and the fifth decade with an even number of cases, i.e. 20 cases $(20.6 \%)$, second decade 13 cases $(13.4 \%)$, first decade 6 cases $(6.2 \%)$, sixth decade 4 cases $(4.1 \%)$, and 2 cases $(2.1 \%)$ of unknown age.

Except IgA deposition, other depositions were also found in various combinations. The three most common findings were $\operatorname{IgA}$ and $\mathrm{C} 3$ which was found in 24 cases $(24.8 \%)$, followed by a combination of $\operatorname{IgA}$, IgM and $\mathrm{C} 3$ in 22 cases (22.6\%), and $\operatorname{IgA}$ alone in 12 cases $(12.4 \%)$.

\section{DISCUSSION}

\section{Nephrotic syndrome}

The most frequent histopathological appearance in childhood as well as in adult nephrotic syndrome was minimal change disease.

Wilawirya ${ }^{5}$ in his study of primary nephrotic syndrome in children in Jakarta has collected 547 cases of new nephrotic syndrome patients during a 10-year period from 1970-1979. Of the 547 cases, 364 were biopsied and of these 55 cases were examined using immunofluorescence and electron microscopy, which was performed in Australia. His study revealed minimal change in 161 cases $(44.2 \%)$, mesangial proliferative glomerulonephritis 139 cases $(38.2 \%)$, focal segmental glomerulosclerosis 24 cases $(6.6 \%)$, membranoproliferative glomerulonephritis 19 cases (5.2\%), membranous glomerulonephritis 8 cases $(2.2 \%)$, and sclerosing glomerulonephritis 13 cases (3.6\%). In an earlier report by Kasim et $\mathrm{al}^{2}$ in 26 cases of childhood nephrotic syndrome, the figures were minimal change 12 cases $(46.1 \%)$, mesangial proliferative glomerulonephritis 7 cases $(26.9 \%)$, focal segmental glomerulosclerosis and sclerosing glomerulonephritis with 3 cases each $(3.8 \%)$, and only one case $(3.8 \%)$ with membranoproliferative glomerulonephritis. Compared to these previous studies, there is a striking difference with the present study in which membranoproliferative glomerulonephritis ranked as number two with $13 \%$ of the cases, while in the previous studies it comprised only $5.2 \%$ and $3.8 \%$ repectively. In the previous studies no cases of IgA nephropathy were encountered, while in the present study 5 cases $(2.8 \%)$ were found.

Reports from Indonesia about childhood nephrotic syndrome showed a striking difference compared to a report in 1978 by the ISKDC (International Study of Kidney Disease in Children) in the prevalence of minimal change nephrotic syndrome (MCNS) versus nonminimal change nephrotic syndrome (NMCNS). ISKDC $^{6}$ found MCNS $76.4 \%$ and NMNCS $23.6 \%$, while Kasim et al ${ }^{2}$ found $46.1 \%$ and $53.9 \%$, Wilawirya et $\mathrm{al}^{7} 44.2 \%$ and $55.8 \%$ and Damanik et $\mathrm{al}^{8} 46.4 \%$ and $53.6 \%$. In the present study the figures were $58.2 \%$ and $41.8 \%$. Thus in this study the prevalence of MCNS is higher as compared to previous reports from Indonesia, but still significantly lower than reported by the ISKDC. Further studies should be performed to look for the reasons of this shift.

van Buuren et $\mathrm{al}^{9}$ in a study of nephrotic syndrome in Namibian children found that the pattern differed greatly from the non-African pattern, i.e. the most frequent pattern was $\mathrm{HBV}$-associated membranous glomerulonephritis $(38.2 \%)$, while minimal change disease was seldom encountered (7.4\%). From 1975 to 1988 they have managed 70 black children and among these 29 were hepatitis B virus carriers. Of the 29, 26 had membranous glomerulonephritis, 1 membranoproliferative glomerulonephritis, 1 focal segmental glomerulosclerosis and 1 was not biopsied due to advanced renal failure.

Woo et al. ${ }^{10}$ in 1999 reported that the commonest from of nephrotic syndrome in Singapore is now minimal change disease $(30 \%)$, while mesangial glomerulonephritis was found in $25 \%$ of all primary nephrotic syndrome.

Nephrotic syndrome affected males more often than females. In childhood nephrotic syndrome Wilawirya et $\mathrm{al}^{7}$ from Jakarta and Damanik et $\mathrm{al}^{8}$ from Yogyakarta, reported the male to female ratio as 1.3:1 and 2.4:1 respectively. In this study is was $2.0: 1$ for children and 1.4:1 for adults.

\section{Lupus nephritis}

Compared to a previous report in 1981 by Himawan et al, ${ }^{11}$ there is a striking difference in the distribution 
of the classes. In the present study the predominant class is Class IV with $58.7 \%$ of the cases, far above the other classes which were about evenly distributed between 9.1 and $9.9 \%$. While in the previous study Class IV comprised only $39 \%$ of the cases, followed by Class III 33\%, Class II 17\%, and Class I and Class $\mathrm{V} 6 \%$ each. Mok et al. ${ }^{12}$ in their study of lupus nephritis in Southern Chinese patients found that 55\% of their cases were Class IV, which is about the same as in the present study, followed by Class III (25\%), Class V (14\%), Class II (5\%), and Class I (1\%).

\section{IgA Nephropathy}

In this study $\operatorname{Ig} A$ nephropathy was found in $11.5 \%$ of all biopsies. Previous reports from Jakarta by Hariandja et al. ${ }^{3}$ and Himawan and Endardjo ${ }^{14}$ revealed a percentage of 9.8 and $14.6 \%$ respectively. Woo et al. ${ }^{10}$ reported that in Singapore IgA nephropathy is still the commonest primary glomerulonephritis ranging from $42 \%-45 \%$ during the past two decades.

The male to female ratio was $1.7: 1$, the same as previously reported by Effendi et al. ${ }^{15}$ (1.75:1), but different from the report by Himawan and Endardjo ${ }^{14}$ who found a ratio of $2.8: 1$. Sidabutar et al ${ }^{16}$ reported that in their series the clinical presentation of patients with IgA nephropathy were nephrotic syndrome $35.71 \%$, rapidly progressive glomerulonephritis $3.57 \%$ and glomerulonephritis without nephrotic syndrome $60.75 \%$. They found $\operatorname{IgA}$ deposits alone in $28.57 \%$, much more as compared to the present study (12\%).

In summary, this study revealed that minimal change disease is the most common type of glomerulonephritis in childhood as well as in adult nephrotic syndrome, i.e. $58.2 \%$ and $44.7 \%$ respectively. Compared to previous studies from Indonesia there was a change in the proportion of minimal change versus non-minimal change cases in childhood nephrotic syndrome. In this study the result was $58.2 \%$ versus $41.8 \%$, while in previous studies it was ranging from $44.2 \%-46.4 \%$ versus $53.6 \%-55.8 \%$.

In lupus nephritis, like all other studies, the female preponderance was very striking, with a M:F ratio of 1:7.9. Most cases were of WHO-Class IV (58.7\%), and the peak incidence was in the fourth decade (45\%).

IgA nephropathy was more prevalent among males with a M:F ratio of $1.7: 1$. The peak incidence was in the fourth decade (33\%), and the most common histopathological appearance were diffuse sclerosing glomerulonephritis (35\%) and mesangial proliferative glomerulonephritis (34\%).

\section{Acknowledgement}

The author is indebted to Dr. Sutjahjo Endardjo, MSc who performed the immunofluorescence microscopy examinations and Drs. Rino Pattiata and Diah Rini Handjari for their invaluable help and assistance in this study.

\section{REFERENCES}

1. Sutedjo, Wahidijat I. Biopsi ginjal pada anak-anak penderita "nephrotic syndrome". Maj Ked Indon 1963; 12:1.

2. Kasim JA, Himawan S, Wilawirya IGN. Renal biopsy in children with nephrotic syndrome. A morphological study (Preliminary report). Paediatr Indon 1972; 12:55-67.

3. Churg J, Sobin LA. Renal disease. Classification and atlas of glomerular diseases. Tokyo: Igaku-Shoin; 1982.

4. Churg J, Bernstein J, Glassock RJ. Renal disease. Classification and atlas of glomerular diseases. $2^{\text {nd }}$ ed. New York: Igaku-Shoin; 1995.

5. Wilawirya IGN. Penelitian beberapa aspek klinis dan patologi anatomis sindrom nefrotik primer pada anak di Jakarta (disertasi). Jakarta: Univ Indonesia; 1992.

6. International Study of Kidney Disease in Children. The nephrotic syndrome in children. Prediction of histopathology from clinical and laboratory characteristics at the time of diagnosis. Kidney Int 1978; 3:159-65.

7. Wilawirya IGN, Alatas H, Tambunan T, Himawan S. Gambaran histopatologis ginjal pada sindrom nefrotik primer di Jakarta. Presented at the Kongres Nasional Ilmu Kesehatan Anak IX; 1993 Jun 13-17; Semarang, Indonesia.

8. Damanik MP, Endardjo S, Himawan S. Gambaran histopatologik sindroma nefrotik pada anak. Presented at the Kongres Nasional Ilmu Kesehatan Anak X; 1996; Bukittinggi.

9. van Buuren AJ, Bates WD, Muller N. Nephrotic syndrome in Namibian children. S Afr Med J 1999; 89:1088-91. Abstract.

10. Woo KT, Chiang GS, Pall A, Tan PH, Lau YK, Chin YM. The changing pattern of glomerulonephritis in Singapore over the past two decades. Clin Nephrol 1999;52:96-102. Abstract.

11. Himawan S, Siregar B, Endardjo S. Gambaran mikroskopik cahaya dan imunofluoresensi nefritis lupus. Beberapa pengalaman di Jakarta. Makalah Lengkap Kongres Nasional VII Ikatan Ahli Patologi Indonesia; 1981 Jun 15-19; Medan, Indonesia.

12. Mok CC, Wong RW, Lau CS. Lupus nephritis in Southern Chinese patients: clinicopathologic findings and long-term outcome. Am J Kidney Dis 1999; 34:315-23.

13. Hariandja A, Hutagalung $P$, Endardjo $S$, Himawan $S$, Sidabutar RP. IgA nephropathy in Jakarta (Tjikini Hospital 1980-1985). Presented at the $6^{\text {th }}$ Asian Colloquium in Nephrology; 1985; Kuala Lumpur, Malaysia.

14. Himawan S and Endardjo S. Gambaran histopatologik nefropati IgA di Jakarta. Kumpulan Makalah Lengkap Kongres Nasional X Ikatan Ahli Patologi Indonesia; 1990 Jul 5-8; Surabaya. Patologi Anatomik Cabang Jakarta. p. 96-100. 
15. Effendi I, Sidabutar RP, Himawan S, Endardjo S. IgA nephropathy in Jakarta, Indonesia. Presented at the $9^{\text {th }}$ Asian Colloquium in Nephrology. 1992 May 17-21; Seoul, South Korea.
16. Sidabutar RP, Lumenta NA, Suhardjono, Sumarjono, Siregar $\mathrm{P}$, Alatas $\mathrm{H}$, et al. Glomerulonephritis in Indonesia. Kursus Sehari Imunologi Ginjal. 1987 Aug 20; Jakarta, Indonesia. 